УДК 902.694

DOI 10.25205/1818-7919-2018-17-7-9-17

Корейский полуостров и Японские острова:

сложение особенностей и заимствование культурных традиций в эпоху палеометалла (материалы к учебному курсу «Археология зарубежной Азии»)

\author{
И. С. Гнездилова, А. Л. Нестеркина, Е. А. Соловьева, А. И. Соловьев
}

Институт археологии и этнографии СО РАН

Новосибирск, Россия

Аннотачия

Период наиболее интенсивных контактов древнего населения Корейского полуострова и Японских островов (III-VII вв. н. э.) известен широким распространением традиции строительства курганов, которые позволяют изучать различные аспекты жизни общества, в том числе и культурные контакты. Курганная традиция Кореи связана с эпохой троецарствия (III-VII вв.). Строительство курганов началось в Когурё в I в. до н. э., затем с III в. н. э. в Пэкче, Силла и Кая. Прекратили их строить в середине VI в. вследствие распространения буддизма. Курганы на Японских островах появились еще в период яёй (III в. до н. э. - III в. н. э.), расцвет их строительства пришелся на период кофун (III-VII вв. н. э.). Изучение конструктивных особенностей курганов позволяет сделать вывод о наличии сходства в формах и материалах насыпей, конструкции погребальных камер. Изучаемые территории объединяет культурно-исторический фон - распространение земледелия, основанного на культивации риса, производство бронзовых и железных изделий, появление государственных образований.

Ключевые слова

Корейский полуостров, Японские острова, I в. до н. э. - VII в. н. э., курганы, традиции

Благодарности

Исследование проведено при финансовой поддержке РФФИ (проект № 180900507)

Для циитирования

Гнездилова И. С., Нестеркина А. Л., Соловьева Е. А., Соловьев А. И. Корейский полуостров и Японские острова: сложение особенностей и заимствование культурных традиций в эпоху палеометалла (материалы к учебному курсу «Археология зарубежной Азии») // Вестн. НГУ. Серия: История, филология. 2018. Т. 17, № 7: Археология и этнография. С. 9-17. DOI 10.25205/1818-7919-2018-17-7-9-17

\title{
Korean Peninsula and Japanese Islands: Forming Features and Borrowing Cultural Traditions during the Paleometall Epoch (Materials for Educational Course "Archaeology of Foreign Asia")
}

\author{
I. S. Gnezdilova, A. L. Nesterkina, E. A. Solovieva, A. I. Soloviev \\ Institute of Archaeology and Ethnography SB RAS \\ Novosibirsk, Russian Federation \\ Abstract
}

Purpose. The period of the most intensive contacts of the ancient population of the Korean peninsula and the Japanese Islands $\left(3^{\text {rd }}-7^{\text {th }}\right.$ centuries AD) is of special interest for study. The period witnessed a wide spread of the tradition of

(С) И. С. Гнездилова, А. Л. Нестеркина, Е. А. Соловьева, А. И. Соловьев, 2018 
building burial mounds (kurgans). Due to the artifacts found in the kurgans, it becomes possible to study various aspects of the people's social life, including cultural contacts. We aimed at studying territorial alliances based on the cultural and historical background, such as the spread of agriculture based on wet rice cultivation, bronze and iron production, the emergence of states.

Results. The kurgan tradition on the Korean peninsula is associated with the era of the Three Kingdoms $\left(3^{\text {rd }}-7^{\text {th }}\right.$ centuries $\mathrm{AD}$ ). The tradition of erecting mounds started in Koguryo state in the $1^{\text {st }}$ century BC, then from the $3^{\text {rd }}$ century $\mathrm{AD}$ it continued in Baekje, Silla and Kaya, and disappeared in the middle of the $6^{\text {th }}$ century AD because of adopting Buddhism. Common barrows had stone embankments, but they are also found with earthen mounds. Burial chambers were first constructed vertically, then horizontal ones appeared. On the Japanese Islands, kurgans first appeared during the Yayoi period ( $3^{\text {rd }}$ century BC $-3^{\text {rd }}$ century AD) and were widely constructed during the Kofun period $\left(3^{\text {rd }}-7^{\text {th }}\right.$ centuries AD). The barrows had earthen embankments with burial chambers inside. The barrows differed in the form of their embankment and size. The burials of the Kofun period in Japan continued the Yayoi period traditions to a certain extent. They had earthen embankments and were decorated with bronze mirrors and stone ornaments in the burial chambers. In addition, their feature is clay haniva figurines around the perimeter of the embankment. Starting from approximately the $5^{\text {th }}$ century $\mathrm{AD}$, there began to appear a certain homogeneity in the funerary structures of the Korean peninsula and the Japanese archipelago. Sueci ceramics became a typical element of the funeral rite, as well as bronze and iron objects, gold jewelry and luxury items which appeared in burial chambers. The construction of kurgans acquired some new features, such as stone chambers with side corridors. Both on the Korean Peninsula and the Japanese Islands, we observe similar types of embankments, such as round (embun), square (ho:fun), double round (so:embun), double square (so:ho:fun) and in the form of a "Japanese sea scallop" (hatategaishikikofun).

Conclusion. The study of the structural features of the kurgans on the Korean Peninsula and the Japanese Islands allows us to conclude that there are similarities in the forms and materials of embankments and the forms of burial chamber construction. The main difference is the larger size of Japanese kurgans. The similarities we revealed can be explained by the mutual influence of the population of the Korean peninsula and the Japanese islands.

Keywords

Korean peninsula, Japanese islands, $1^{\text {st }}$ century $\mathrm{BC}-7^{\text {th }}$ century $\mathrm{AD}$, burial mounds, tradition

\section{Acknowledgements}

The work was supported by the Russian Foundation for Basic Research, project 180900507

\section{For citation}

Gnezdilova I. S., Nesterkina A. L., Solovyeva E. A., Solovyev A. I. Korean Peninsula and Japanese islands: Forming Features and Borrowing Cultural Traditions during the Paleometall Epoch (Materials for Educational Course "Archaeology of Foreign Asia"). Vestnik NSU. Series: History and Philology, 2018, vol. 17, no. 7: Archaeology and Ethnography, p. 9-17. (in Russ.) DOI 10.25205/1818-7919-2018-17-7-9-17

Начиная с эпохи раннего металла, древние культуры Корейского полуострова и Японского архипелага развивались в постоянном взаимодействии. Наибольшей интенсивности контакты древнего населения этих территорий достигли в III-VII вB. н. э. В этот период в обоих регионах повсеместно получили распространения сходные по ряду базовых признаков памятники - курганы. Они представляют собой уникальные по своей концепции объекты и в то же время маркеры особой исторической эпохи как для Корейского полуострова, так и для Японского архипелага. Возникновение феномена близкого сходства данных комплексов требует специального исследования и объяснения его с привлечением широкого круга источников.

Актуальность данной темы связана с важнейшей ролью, которую сыграли контакты носителей восточноазиатских традиций - островной и материковой, в дальнейшей истории Кореи и Японии. Изучение начального этапа данного процесса, определение направлений взаимодействия двух культурных традиций, выявление особенностей и общих черт на примере курганных конструкций представляется крайне значимым. Проведение сравнительного изучения памятников курганного типа предпринимается в отечественной науке впервые, что и определяет новизну исследования. Главной целью является исследование конструкций курганных комплексов Корейского полуострова и Японских островов. Реализация поставленной цели предполагает решение нескольких задач: изучить конструкцию курганных комплексов Корейского полуострова и Японских островов эпохи палеометалла, определить сходство и различие в формах курганов, выявить сходные конструктивные элементы и предположить 
направления влияния культурных традиций. Целью данной публикации является также знакомство студенческой аудитории с важными процессами древней истории населения Японских островов и Корейского полуострова, особенностями культурных контактов.

На Корейском полуострове данное время соответствует периоду троецарствия, который получил в литературе также название - «эпоха курганов». В японской археологии за данным временем закрепилось наименование «кофун», что дословно переводится как «период курганов». Для этого временного интервала курганы являются самым полным источником для изучения различных аспектов жизни общества, в том числе и его внешних культурных контактов. Кроме того, общие черты задает культурный фон - на обеих территориях распространено сельское хозяйство, основанное на влажной культивации риса, производство бронзовых изделий, основы которого были привнесены на территорию Японского архипелага с территории Кореи.

Следует отметить, что исторический фон на изучаемых территориях заметно различался. Если в целом характеризовать политические процессы, происходившие на Корейском полуострове, то данный период представлял собой время конфликтов, вооруженных столкновений различных государственных образований, имевших собственные отличительные черты. На Японских же островах происходило постепенное распространение власти политического центра Ямато и интеграция прилегающих районов сначала на острове Кюсю, затем далее на северо-восток. Корейский полуостров в силу географического положения, особенно северная его часть, испытывал сильное, в том числе и культурное, влияние со стороны императорского Китая. Японский архипелаг испытал это в меньшей степени - сказалась специфика его географического положения. Фиксируемые культурные импульсы со стороны Срединного государства достигали его территории в значительной мере опосредованно, через Корейский полуостров. Это касается как проникновения буддизма и иероглифической письменности в более поздние эпохи, так и появления на островах предметов материальной культуры, навыков производства изделий из металла, строительства различных сооружений [Ямамото, 2018. C. 38].

Курганы начали строить в Когурё еще в I в. до н. э., в Пэкче - с начала III в., в Силла и Кая - с середины III в. Предшественниками курганов на Корейском полуострове (IV-II вв. до н. э.) являются каменные ящики (Кведжондон, Намсонри, Тонсори) или грунтовые могилы (Тэгонни, Чхопхори) с деревянным гробом. В верхней части заполнения этих могил обнаружено большое количество обломков породы, которые изначально составляли насыпь.

Ранние курганы Корейского полуострова были одиночными сооружениями небольших размеров с погребальной камерой вертикального типа. Расцвет курганной традиции на Корейском полуострове пришелся на эпоху троецарствия (III-VII вв.). В это время появились монументальные курганы с земляной насыпью длиной более 100 м, с горизонтально и вертикально расположенными погребальными камерами («силлаского» типа), в которых обнаружено большое количество погребального инвентаря. В конце VI в. курганная традиция в Корее переживала упадок: размеры насыпей и количество инвентаря в их камерах уменьшалось. Прекратили их строить в середине VII в. [Ким Гиун, 2000. С. 7; Ким Гильсик, 2017]. Данное явление, как предполагают исследователи, связано с распространением буддизма в Корее и, как следствие, изменением погребального обряда [Ким Гильсик, 2017].

Насыпи курганов сооружались из земли или камня.

Каменные характерны для ранней традиции Когурё и Пэкче. Они часто имели четырехугольную ступенчатую форму, обычно с 3-5 и более ступенями. Центром распространения строений со ступенчатой формой насыпи являлось Когурё. Типичным ступенчатым курганом культуры Когурё можно назвать могилу Чангунчхон («Мавзолей полководца») 412 г. в провинции Цзилинь Китайской Народной Республики, которая в древности входила в состав корейского государства Когурё (рис. $1,1,2)^{1}$. Курган представляет собой сложенную из

\footnotetext{
${ }^{1}$ Фотографии, за исключением специально оговоренных случаев, выполнены А. И. Соловьевым во время научных командировок.
} 
огромных каменных блоков семиступенчатую пирамиду высотой 11,3 м и 29,3 × 29,7 м в основании, возведенную на цоколе двухметровой высоты [Ким Гиун, 2000. С. 13-14]. Последовательность возведения курганов с каменной насыпью выглядела следующим образом: сначала на уровне древней дневной поверхности устраивали подсыпку из камня, на которой после совершения захоронения возводилась насыпь, строился каменный ящик или сооружалась каменная комната-гробница.

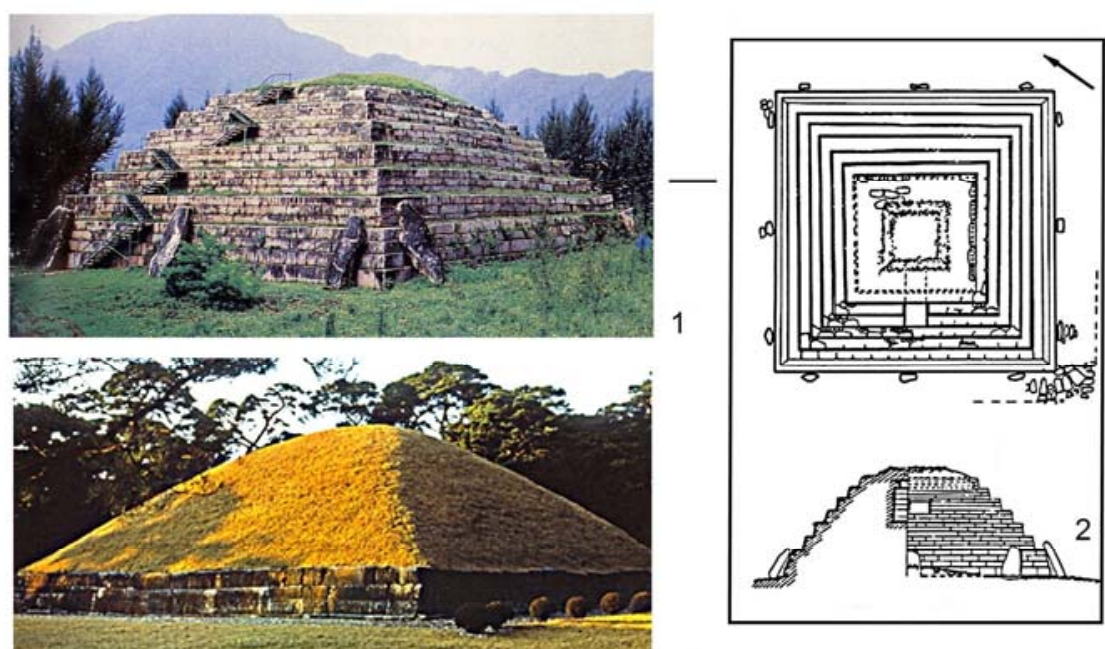

3
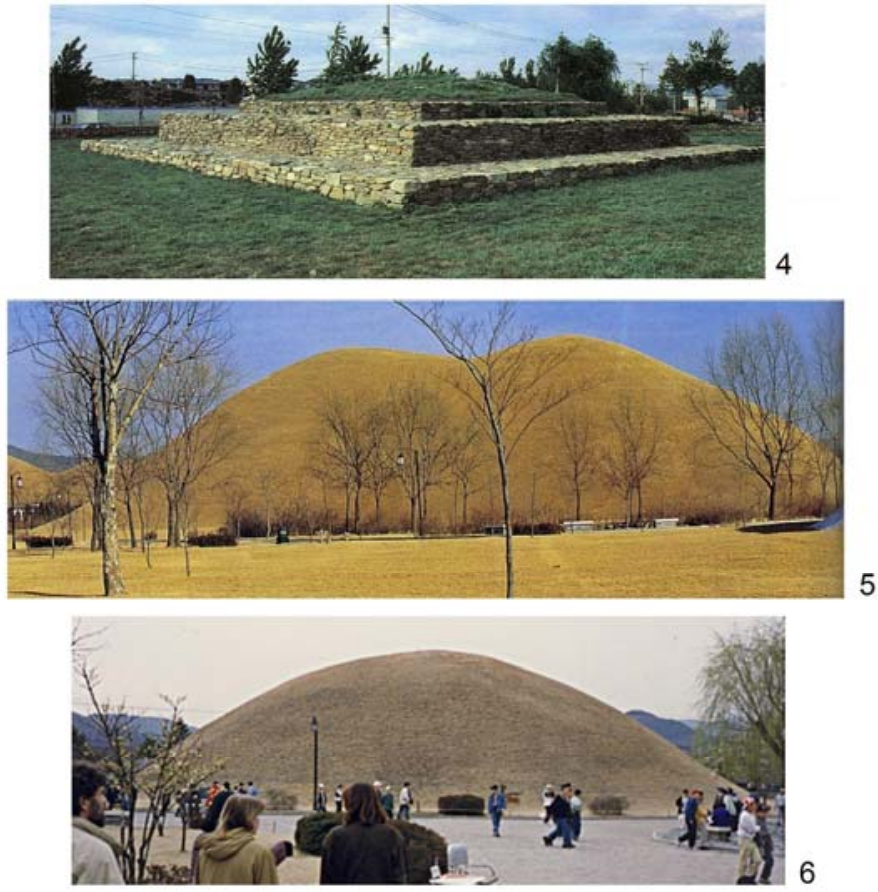

Рuc. 1. Курганы Корейского полуострова:

1, 2 - Чангунчхон («Мавзолей полководца»); 3 - «Могила короля Тонмёна»; 4 - Сокчхондон; 5 - Хваннамдэчхон; 6 - Чхонмачхон («Гробница летящей лошади») (1-3, 5 по: [Ким Гиун, 2000])

Fig. 1. Mounds of the Korean Peninsula:

1, 2 - Changuncheon (“Commander's Mausoleum”); 3 - "The Tomb of King Tonmyon”; 4 - Sokchondon; 5 - Hwannamdachon; 6 - Chonmacheon ("Tomb of the Flying Horse") (1-3, 5 by: [Kim Kiun, 2000]) 
Когурёские курганы с земляной насыпью считаются более поздними. Они представляют собой строения с каменной комнатой, расположенной на уровне древней дневной поверхности или слегка углубленной в грунт, поверх которой возводилась земляная насыпь (рис. 1,3 ). Стены каменной комнаты таких курганов часто украшались великолепными фресками [Ким Хёнсук, 2007. С. 224-234]. Для начального периода Пэкче характерны разнообразные формы погребальных сооружений: курганы с простой или ступенчатой каменной насыпью, курганы с каменно-земляной насыпью, каменные ящики с деревянным гробом, погребения в урнах, грунтовые могилы и т. д. [Сон Джонъён, Со Хёнджу, 2007. С. 261-264]. Широко известны монументальные курганные сооружения с трехступенчатой насыпью могильника Сокчхондон культуры раннего Пэкче, расположенные в черте Сеула [Ким Гиун, 2000. С. 30-31] (рис. 1, 4). Считается, что такие курганы начали сооружаться в Пэкче в результате влияния со стороны Когурё; к последствиям когурёского влияния относят и традицию строительства курганов с каменными комнатами, которая получила широкое распространения в поздний период Пэкче [Сон Джонъён, Со Хёнджу, 2007. С. 264-267].

Курганы с земляной насыпью были особенно популярны в Силла и Кая. В Силла они часто сооружались на каменном фундаменте [Ким Ёнсон, 2007. С. 311-315]. Насыпи имели округлую или 8-образную в плане форму. Типичным примером такого сооружения является могила Хваннамдэчхон в г. Кёнджу на юго-востоке Корейского полуострова, которая состоит из двух соединенных вместе насыпей диаметром 82 м, высотой 23 м [Ким Гиун, 2000. С. 6263] (рис. 1, 5). Пространство по периметру курганов часто ограничивалось подобием каменной оградки или рвом. Погребальные камеры сооружались до или после возведения курганной насыпи. На ранних этапах они были вертикальными, сооружались из камня или представляли собой грунтовую яму. На поздних этапах (IV-VI вв.) были популярны однои многокамерные курганы с погребальными камерами горизонтального типа с коридором или без него, которые сооружались, в основном, из каменных блоков. Типичным примером конструкции с горизонтально расположенной каменной погребальной камерой является курган Сансанчхон в г. Кёнджу [Ким Гиун, 2000. С. 70-71]. В культуре Силла сформировался особый тип погребальной камеры: она строилась из дерева, а после совершения захоронения засыпалась обломками породы, над которыми возводилась земляная насыпь. К данному типу относятся такие широко известные курганы, как «Могила золотой короны» Кылмгванчхон и могила «Гробница летящей лошади» Чхонмачхон [Ким Гиун, 2000. С. 63-64] (рис. 1, б). В большинстве случаев тело умершего помещалось в погребальную камеру в деревянном гробу или керамической урне.

Погребальный инвентарь варьировался в зависимости от района, культурной принадлежности и датировки. В целом, инвентарь включал предметы, указывающие на прижизненный социальный статус или род занятий погребенного: личные украшения, предметы конской упряжи, оружие и доспехи, орудия труда, керамические сосуды. В насыпях курганов и у входов в камеры часто находили предметы, связанные с поминальными ритуалами. В Когурё и Пэкче сами предметы погребального инвентаря часто заменяли их изображением на стенах погребальных камер курганов.

Традиция захоронения в курганах на Японских островах брала свое начало еще в период яёй (III в. до н. э. - III в. н. э.) и продолжалась в следующую эпоху. Это земляные насыпи, помещение в погребения бронзовых зеркал, каменных украшений. При этом появились такие специфические черты, как помещение глиняных фигур ханива по периметру насыпи.

К концу периода яёй возникла традиция погребения в курганах фукюбо, представляющих собой круглую либо квадратную насыпь, окруженную рвом с водой и дамбой через него. Такие погребения могли стать прототипами квадратно-круглых курганов периода кофун (III-VII вв.), которые получили широкое распространение с III в. н. э. Все большие курганы периода кофун в Японии (с длиной основания более 200 м) только квадратно-круглой формы (рис. 2, 1) [Хиросэ, 2015. С. 64]. Территория их распространения очень обширна: от префектуры Иватэ (на севере) до префектуры Кагосима (на юге о-ва Кюсю) [Imamura, 1996. С. 194]. 
Курганы начального периода имели свои отличия: передняя их часть строилась в форме трапеции, основание которой было значительно больше вершины (т. е. места соединения двух частей). Задняя (круглая) часть у ранних курганов, как правило, выше передней и представляла собой высокую пятиступенчатую насыпь.
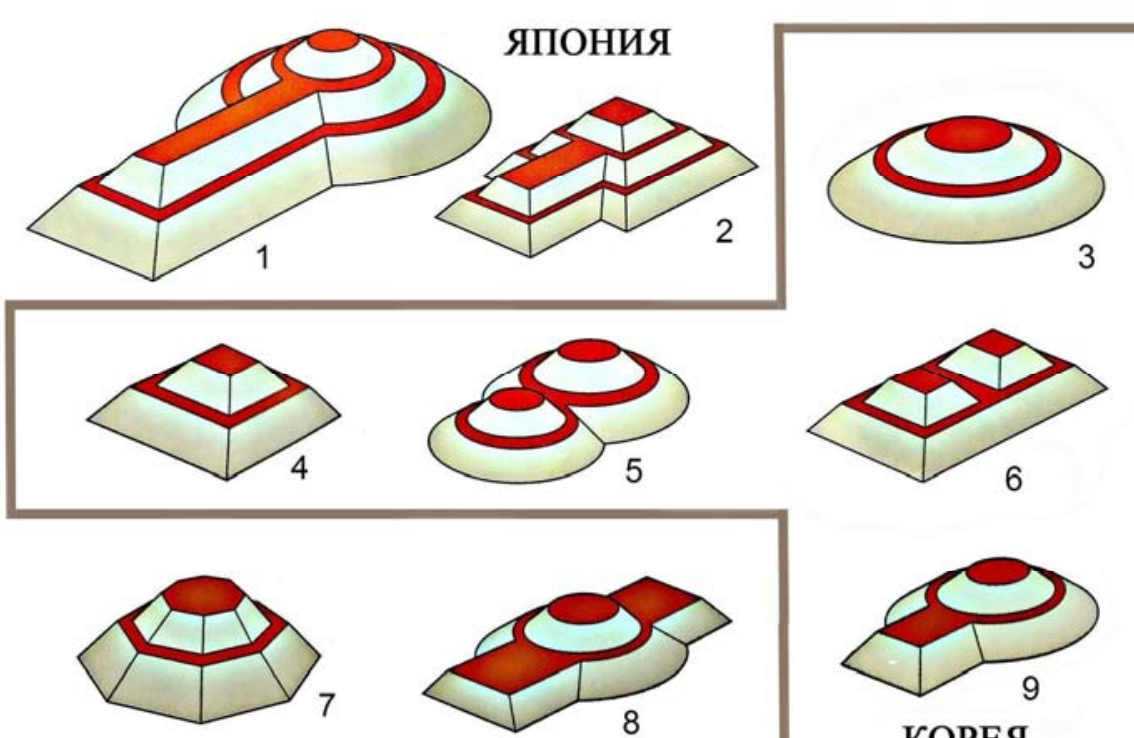

6

\section{ЯпОНИЯ}
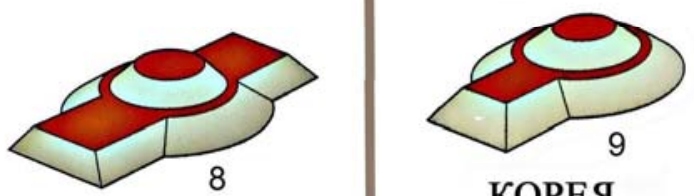

КОРЕЯ, ЯПОНИЯ
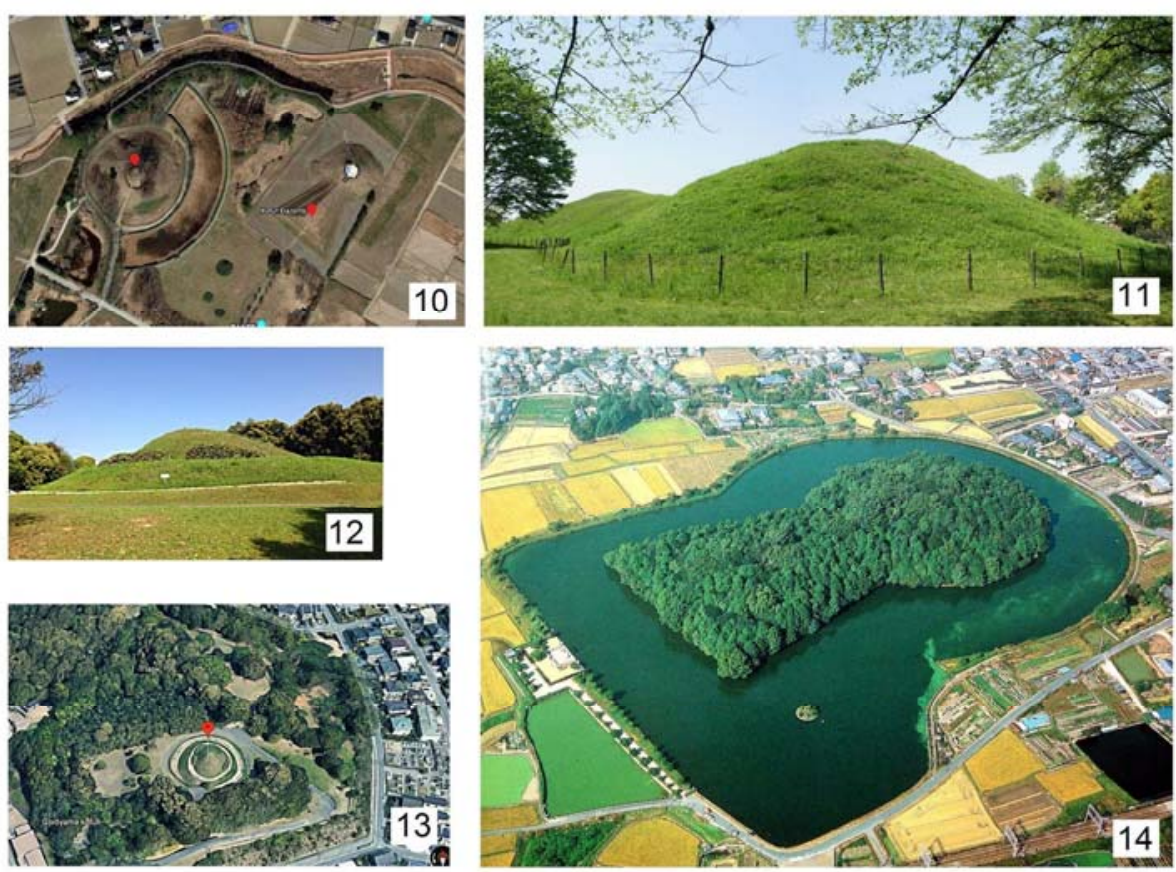

Pис. 2. Курганы Японских островов:

1-9 типы курганов; 10, 11 - курганы Сакитама, префектура Сайтама; 12, 13 - курган Горо: яма, префектура Фукуока; 14 - курган Хо: райсан (мавзолей императора Суйнина), префектура Нара

(14 по: [Yamatono kofun II, 2006])

Fig. 2. Mounds of the Japanese Islands:

1-9 types of burial mounds; 10, 11 - Sakitama mounds, Saitama Prefecture; 12, 13 - Goro: Yama mound, Fukuoka Prefecture; 14 - Ho: Rysan mound (mausoleum of Emperor Suinin), Nara Prefecture

(14 by: [Yamatono kofun II, 2006]) 
В среднем периоде стали возводить курганы, у которых обе насыпи были примерно одной высоты, а передняя часть постепенно превратилась в прямоугольник, ширина основания которого практически сравнялась с диаметром основания круглой части. К этому же времени относится сложение традиции возведения обеих насыпей трехступенчатыми - просуществовала до конца периода кофун [Хиросэ, 2015. С. 66]. У квадратно-прямоугольных курганов (рис. 2,2$)$ задняя насыпь имела в основании форму квадрата. Такие курганы в длину не превышали 180 м. На территории Японии их число относительно невелико - около 500 погребений. Круглые курганы (рис. 2, 3) составляют 90 \% всех таких памятников периода кофун и распространены по всей территории Японии.

Со второй половины VI в. постепенно квадратные курганы (рис. 2, 4) сменялись квадратно-круглыми, маркируя погребения глав кланов и местных вождей. Они получили наибольшее распространение в районах Кинки и Канто.

Двойной круглый курган (рис. 2, 5) внешне выглядел как две соединенных друг с другом круглых насыпи. Однако внутри он имеет только одну погребальную камеру, но с двумя саркофагами. В настоящее время выявлено только одно подобное сооружение - курган Канаяма (уезд Канан префектуры Осака). Единственным известным двойным квадратным объектом (рис. 2, 6) является курган Футагодзука, обнаруженный в уезде Тайси префектуры Осака. Он имеет вид двух соединенных квадратных насыпей [Хиросэ, 2015. С. 41]. Как и двойные круглые, двойные квадратные курганы выделяются в отдельный тип, поскольку подобная форма создавалась целенаправленно, а не являлась результатом случайного «соседства».

Курганы в форме многоугольников (рис. 2, 7) сооружались в период Асука для погребения родственников императора. К настоящему времени изучены три погребальных комплекca, имеющих в основании шестиугольник. Наиболее известен курган Марукояма (дер. Асука префектуры Нара) [Хиросэ, 2015. С. 41]. В конце VI в. появилась традиция возводить насыпи в виде восьмиугольника, которая связывается с влиянием даосизма, проникавшего из Китая. Такие сооружения пришли на смену квадратно-круглым в качестве императорских усыпальниц. К настоящему моменту обнаружено 12 погребений, к наиболее известным относятся усыпальница императора Дзёмэй (курган Даннодзука), совместная усыпальница императора Тэмму и императрицы Дзито (курган Ногутио:бо), усыпальница императора Момму (курган Накаояма) и др. [Хиросэ, 2015. С. 74].

Парные квадратные с круглой средней частью курганы (рис. 2, 8) относятся к начальному периоду эпохи кофун. Обнаружены на острове Сикоку и побережье острова Хонсю, выходящем к Харимскому морю [Хиросэ, 2015. С. 41]. Наиболее известны курган Кусияма (г. Тенри префектуры Нара), курган Нэкодзука (г. Такамацу префектуры Кагава, о-в Сикоку).

Курганы в форме морского гребешка (рис. 2, 9) отличались от квадратно-круглых короткой квадратной частью и, как правило, общим меньшим размером. Начало их сооружения относится к V в. Вероятнее всего, они строились над захоронениями местных вождей и чиновников невысокого ранга [Хиросэ, 2015. С. 76].

На разных этапах периода кофун менялось устройство погребальных камер. В начальный период создавались вертикально расположенные погребальные камеры (татэана сэкисииу) с глиняным основанием. Для погребения в них использовались деревянные колоды. Стенами камеры служили каменные плиты, которые плотно подгонялись друг к другу. Сверху постройка также перекрывалась плитами. Для герметичности свободные пространства между ними засыпались грунтом либо запечатывались глиняной массой. Внутри получившегося склепа создавались водоотводные каналы. В среднем периоде эпохи кофун (в конце IV - начале $\mathrm{V}$ в.) отмечается сооружение горизонтально расположенных погребальных камер (ёкоана сэкисииу), для погребения внутри которых стали использоваться каменные саркофаги. При создании горизонтальных камер могли применяться мегалиты. Прекращение практики строительства курганов стало следствием принятия буддизма и применения практики кремации.

Примерно с V в. в погребальных сооружениях Корейского полуострова и Японского архипелага начало проявляться сходство, которое можно рассматривать даже как явную одно- 
родность. Среди общих для Корейского полуострова и Японских островов форм курганных построек следует выделить круглые, квадратные, двойные круглые, двойные квадратные и в форме морского гребешка строения (рис. 2, 3-6, 9). На территории Японских островов в период кофун наиболее распространены круглые курганы (рис. 2, 12, 13), аналогичными которым являются курганы Силла и Пэкче в южной части Корейского полуострова. При этом наиболее известным и значимым с точки зрения социальной иерархии типом курганов на Японских островах становится квадратно-круглый (рис. 2, 10, 11). В Корее в качестве аналога квадратно-круглым курганам Японии, вероятно, можно рассматривать 13 объектов с длиной насыпи от 24 до 76 м, расположенных во внутриконтинентальных районах юго-запада полуострова (провинция Чолла-намдо). Не все такие строения можно точно датировать, однако находки цилиндрических глиняных фигур типа ханива и деревянных ритуальных предметов, оставленных в свое время на поверхности на некоторых сооружений, позволяют отнести их к концу V - началу VI в., хотя данный вопрос остается дискуссионным. Под курганными насыпями, начиная с $\mathrm{V}$ в., появились каменные комнаты с боковыми коридорами [Ямамото, 2018. С. 38]. Керамика суэки стала типичным элементом погребального обряда как на Японских островах, так и на Корейском полуострове; встречаются изделия из железа, золотые украшения, предметы роскоши.

Но если конструктивные элементы курганных сооружений приобретали со временем общие черты, то размеры этих сооружений стали ключевым различием для погребальной архитектуры Корейского полуострова и Японских островов. Курганы Японского архипелага характеризуются большими размерами, причем, чаще всего, размеры кургана напрямую связаны с положением погребенного человека в обществе (рис. 2, 14).

Выделенные в результате изучения курганов Корейского полуострова периода троецарствия и Японских островов периода кофун их общие черты позволяют говорить о наличии в эпоху палеометалла единства в формах, конструкциях и погребальном инвентаре. Таким образом, можно сделать вывод о процессах взаимопроникновения элементов культуры населения этих двух территорий.

Материалы данного обзора могут способствовать повышению мотивации студентов к изучению археологии Восточной Азии, культурных контактов древнего населения региона, могут быть полезны при выборе тем и написании курсовых и дипломных работ.

\section{Список литературы / References}

Imamura K. Prehistoric Japan. New Perspectives on Insular East Asia. Honolulu, University of Hawai'i Press, 1996, 246 p.

Кан Хёнсук. Когурё // Хангук когохак каный (Лекции по археологии Кореи). Сеул: Хангук когохакхве, 2007. С. 223-254. (на кор. яз.)

Kan Khensuk. Kogure [Kogure]. Khanguk kogokhak kanyi [Lectures on the Archaeology of Korea; Kogure]. Seoul, Khanguk kogokhakkhve, 2007, p. 223-254. (in Kor.)

Ким Гиун. Кобун (Курганы). Сеул: Тэвонса, 2000. 120 с. (на кор. яз.) Kim Giun. Kobun [Mounds]. Seoul, Tevonsa, 2000, 120 p. (in Kor.)

Ким Гильсик. Кобун (Курганы) // Хангук когохак чонмун саджон (Кобунпхён) (Специализированный справочник по археологии Кореи). 02.08.2017. URL: http://portal.nrich.go.kr/ kor/archeologyUsrView.do?menuIdx=797\&idx=2739\&st_char=\&sk= (дата обращения 26.08.2017) (на кор. яз.)

Kim Gilsik. Kobun [Kurgans]. Khanguk kogokhak chonmun sadzhon (Kobunpkhen) [Specialized Referencebook on Archaeology of Korea], 02.08.2017. Available at: http://portal.nrich.go.kr/kor/ archeologyUsrView.do?menuIdx= $797 \&$ idx $=2739 \& s t \_c h a r=\& s k=($ accessed 26.03.2017) (in Kor.)

Ким Ёнсон. Силла // Хангук когохак каный (Лекции по археологии Кореи). Сеул: Хангук когохакхве, 2007. С. 301-330 (на кор. яз).

Kim Enson. Silla [Silla]. Khanguk kogokhak kanyi [Lectures on Archaeology of Korea]. Seoul, Khanguk kogokhakkhve, 2007, p. 301-330. (in Kor.) 
Лим Ёнджин. Кванджу Вольгедон-ый чангобун 2-ги (Два квадратно-круглых кургана Вольгедон в г. Кёнджу) // Хангук когохакпо (Археология Кореи). 1994. № 31. С. 237-264 (на кор. яз.)

Lim Ëndzhin. Kvandzhu Vol'gedon-yi changobun 2-gi [Two square-rounded Volgedon mounds in the city of Gyeongju']. Khanguk kogokhakpo [Archaeology of Korea], 1994, no. 31, p. 237-264. (in Kor.)

Сон Джонъён, Со Хёнджу. Пэкче // Хангук когохак каный (Лекции по археологии Кореи). Сеул: Хангук когохакхве, 2007. С. 255-2300 (на кор. яз.)

Son Dzhon'en, So Khendzhu. Pekche [Pekche]. Khanguk kogokhak kanyi [Lectures on Archaeology of Korea]. Seoul, Khanguk kogokhakkhve, 2007, p. 255-2300. (in Kor.)

Хиросэ К. Тисики дзэро кара но кофун ню:мон. [古墳入門ゼロからの知識] (Введение в изучение эпохи кофун). Токио: Гэнто:ся, 2015. 174 с. (на яп. яз.)

Hirose K. Tisiki ero kara no kofun nyu: mon [An Introduction to Studying Kofun Period]. Tokyo, Gentosha, 2015, 174 p. (in Jap.)

Ямамото Т. Кодай канханто: то яматококу. [倭国と古代韓半島] (Древний Корейский полуостров и страна Ямато). Токио: Чуокорон синся, 2018. 256 с. (на яп. яз.)

Yamamoto T. Kodai kanhanto to yamatokoku [Ancient Korean Peninsula and Yamato Country]. Tokyo, Chuokoron shinsha, 2018, 256 p. (in Jap.)

Ямато-но кофун II [大和古墳 II]. (Курганы Ямато II). Киото: Дзимбунсёин, 2006. 188 с. (на яП. яз.)

Yamatono kofun II [Burial mounds of Yamato II]. Kyoto, Jimbunshoin, 2006, 188 p. (in Jap.)

Материал поступил в редколлегию Received 24.08.2018

\section{Сведения об авторах / Information about the Authors}

Гнездилова Ирина Сергеевна, младший научный сотрудник Института археологии и этнографии СО РАН (пр. Академика Лаврентьева, 17, Новосибирск, 630090, Россия, gnezdilova06@mail.ru)

Irina S. Gnezdilova, junior researcher at the Institute of Archaeology and Ethnography SB RAS (17 Academician Lavrentiev Ave., Novosibirsk, 630090, Russian Federation, gnezdilova06@mail.ru)

Нестеркина Анастасия Леонидовна, кандидат исторических наук, научный сотрудник Института археологии и этнографии СО РАН (пр. Академика Лаврентьева, 17, Новосибирск, 630090, Россия, a.1.subbotina@yandex.ru)

Anastasiya L. Nesterkina, PhD in History, researcher at the Institute of Archaeology and Ethnography SB RAS (17 Academician Lavrentiev Ave., Novosibirsk, 630090, Russian Federation, a.1.subbotina@yandex.ru)

Соловьёва Елена Анатольевна, кандидат исторических наук, научный сотрудник Института археологии и этнографии СО РАН (пр. Академика Лаврентьева, 17, Новосибирск, 630090, Россия, easolovievy@mail.ru)

Elena A. Solovieva, PhD in History, researcher at the Institute of Archaeology and Ethnography SB RAS (17 Academician Lavrentiev Ave., Novosibirsk, 630090, Russian Federation, easolovievy@mail.ru)

Соловьёв Александр Иванович, доктор исторических наук, ведущий научный сотрудник Института археологии и этнографии СО РАН (пр. Академика Лаврентьева, 17, Новосибирск, 630090, Россия, easolovievy@mail.ru)

Aleksander I. Soloviev, Doctor of History, leading researcher at the Institute of Archaeology and Ethnography SB RAS (17 Academician Lavrentiev Ave., Novosibirsk, 630090, Russian Federation, easolovievy@mail.ru) 